\title{
Reservoir of Bacterial Exotoxin Genes in the Environment
}

\author{
Veronica Casas, Joseph Magbanua, Gerico Sobrepeña, Scott T. Kelley, and Stanley R. Maloy \\ Department of Biology, Center for Microbial Sciences, San Diego State University, 5500 Campanile Drive, \\ San Diego, CA 92182-1010, USA \\ Correspondence should be addressed to Stanley R. Maloy, smaloy@sciences.sdsu.edu
}

Received 25 October 2010; Accepted 12 December 2010

Academic Editor: Barbara H. Iglewski

Copyright (c) 2010 Veronica Casas et al. This is an open access article distributed under the Creative Commons Attribution License, which permits unrestricted use, distribution, and reproduction in any medium, provided the original work is properly cited.

\begin{abstract}
Many bacteria produce secreted virulence factors called exotoxins. Exotoxins are often encoded by mobile genetic elements, including bacteriophage (phage). Phage can transfer genetic information to the bacteria they infect. When a phage transfers virulence genes to an avirulent bacterium, the bacterium can acquire the ability to cause disease. It is important to understand the role played by the phage that carry these genes in the evolution of pathogens. This is the first report of an environmental reservoir of a bacterial exotoxin gene in an atypical host. Screening bacterial isolates from the environment via PCR identified an isolate with a DNA sequence $>95 \%$ identical to the Staphylococcus aureus enterotoxin A gene (sea). 16 S DNA sequence comparisons and growth studies identified the environmental isolate as a psychrophilic Pseudomonas spp. The results indicate that the sea gene is present in an alternative bacterial host, providing the first evidence for an environmental pool of exotoxin genes in bacteria.
\end{abstract}

\section{Introduction}

Exotoxins are secreted polypeptides produced by certain bacterial pathogens. Many exotoxin genes are carried on mobile genetic elements, including bacterial viruses (bacteriophage or phage). These virulence genes are responsible for many of the symptoms associated with the human disease [1$3]$. As highly mobile genetic elements, phage can readily move between different environments, and are generally more resistant to environmental stress than their bacterial counterparts [4-11]. As a result, phage may survive in the environment in reservoirs not yet characterized. Living in these environmental reservoirs, the phage can influence evolution of the bacteria within these environments in several different manners. Horizontal gene transfer between the phage and the bacterium can result in the rapid evolution of new pathogens and may have serious implications in public health [12].

When a phage infects a bacterium, two alternative possibilities may result. One possibility is that the phage can replicate itself using phage and host factors, resulting in lysis of the bacterial host and release of new phage (the lytic lifestyle). Alternatively, the phage can integrate into the bacterial genome and the bacterial host can utilize certain genes the phage carries in its genome for its own benefit (the lysogenic lifestyle) [13]. If a phage encodes virulence genes, such as exotoxin genes, the phage could facilitate the transfer of these genes to nontoxigenic bacterial hosts, thereby increasing the exotoxin gene pool.

The toxins of Vibrio cholera (cholera toxin), Escherichia coli (shiga toxin), Corynebacterium diphtheria (diphtheria toxin), and Staphylococcus aureus (enterotoxin A) are encoded by phage [14-17]. The Staphylococcus enterotoxin A (sea) gene carried by virulent strains of $S$. aureus is encoded by multiple phages, including $\phi 11, \phi 12, \phi 13,80 \alpha$, and $42 \mathrm{D}$ [18-21]. Other toxins are carried by phages isolated from $S$. aureus strains from animals, food, and the environment [20, 22-31]. Given that multiple S. aureus toxins are encoded by phage, it is possible that multiple transduction events over time have resulted in the generation of the current virulent $S$. aureus strains. An environmental reservoir of toxin genes would provide novel virulence genes, and the genetic exchange between phage and novel bacterial hosts, could provide the mechanism for evolution of novel human pathogens.

To explore this hypothesis, we cultured environmental bacteria and screened them for a phage-encoded exotoxin gene. In this study, we describe the isolation of bacteria from 
environmental ambient air and the screening of the isolates for the phage-encoded sea gene using an exotoxin-specific colony PCR assay. One isolate was confirmed positive for the sea gene, and the sequence of the sea gene was determined. Using 16S rDNA PCR sequencing and comparison to the nonredundant GenBank nucleotide database, we determined that the environmental isolate was a novel host for the sea exotoxin. This is the first report of an alternative bacterial host from the environment that carries a phage-encoded exotoxin gene that is commonly associated with a different bacterial host.

\section{Results}

2.1. Cultivation and Exotoxin-Specific (sea) PCR Screening of Environmental Isolates. Bacterial isolates were cultivated from the ambient environment by exposing Luria Bertani (LB) plates to air and then incubated at room temperature for $48-72 \mathrm{hr}$. Eighty nine isolates were subcultured into sterile 96-well plates containing LB with 15\% glycerol, and grown with aeration for $48-72 \mathrm{hr}$. Using colony PCR specific for the Staphylococcus enterotoxin A (sea) gene, each of the cultivated environmental isolates was screened for the presence of the sea gene. Of 89 isolates screened, one putative sea positive isolate was identified. The isolate was single colony purified, and the sea PCR was repeated on this purified isolate to confirm that the isolate (SEAB3C070426 lab-designated identification) was positive for the sea gene. The resulting sea-specific PCR product was gel-purified and sequenced.

2.2. Characterization of Environmental Isolate. The cultivated and purified environmental isolate "SEAB3C070426" was microbiologically characterized by Gram staining and microscopic evaluation. The environmental isolate was identified as a Gram negative rod. Furthermore, the purified isolate's growth characteristics were evaluated against a $S$. aureus known to carry the sea exotoxin gene ( $S$. aureus Food Research Institute 913 strain). The environmental isolate did not grow on $S$. aureus enrichment media at $35^{\circ} \mathrm{C}$ [32], but grew on LB at room temperature after $48-72 \mathrm{hr}$. In contrast, the $S$. aureus FRI913 control grew on both the enrichment media and LB at both temperatures.

To molecularly identify the cultivated environmental isolate carrying the sea sequence, $16 \mathrm{~S}$ rDNA colony PCR was performed and the resulting PCR product was sequenced. The resulting 16S rDNA sequence was imported into the ARB bacterial $16 \mathrm{~S}$ rDNA database to identify its nearest relatives for downstream phylogenetic analyses [33]. The 16S rDNA PCR product sequence grouped with Pseudomonas spp. using the ARB alignment. The nearest relatives identified by ARB were exported and used to generate a phylogenetic tree. The phylogenetic analyses of the ambient air isolate, its nearest relatives, and select outgroups (including $S$. aureus) were performed using the PAUP* program (Figure 1) [33]. The consensus tree generated from Maximum Likelihood (ML), Maximum Parsimony (MP), and Neighbor Joining (NJ) analyses grouped the ambient air isolate with Pseudomonas spp., not with S. aureus. The ML, MP, and NJ bootsrap values for the main branches of the consensus tree separating the ambient air isolate from S. aureus and grouping it with Pseudomonas spp. were $\geq 94$. The GenBank Accession number of environmental isolate "SEAB3C070426" is FJ979636.

2.3. Characterization of the sea PCR Product. Sequencing of the sea PCR product obtained from the environmental isolate generated a $280 \mathrm{bp}$ DNA sequence. The nucleotide composition of the amplified sequence was analyzed using BioEdit [34]. The sequence of the amplified PCR product contained a G + C content of $30 \%$ over 92 predicted amino acids. A ClustalW [35] alignment of the translated partial sequence of the sea-related gene with known sea genes is presented in Figure S1 in Supplemental Material available online at doi: doi:10.1155/2010/754368. A BLASTN alignment of the sequence against the nonredundant GenBank database confirmed that the amplified PCR product shared 95-96\% nucleotide sequence identity with known sea genes. Most notably, the amplified PCR product was $96 \%$ similar to a known $S$. aureus phage, $\phi \mathrm{NM} 3$. A multiple alignment of the partial sequence of the sea-related gene and guide tree of the top BLASTN hits were produced using ClustalX2 [36] (Figures 2 and 3). BLASTN alignment of the sea-related gene against annotated $S$. aureus genomes from The SEED database was also performed [37]. This alignment indicated the sea-related gene was related to other $S$. aureus phageassociated enterotoxin genes (supplementary Figure S2). The sea-related gene was uploaded to the GenBank database and the Accession number is HQ698309.

\section{Discussion}

Transfer of exotoxin genes to new, as yet uncharacterized, bacterial hosts may facilitate the evolution of novel human pathogens. Many of the exotoxins produced by phageencoded genes target key eukaryotic cellular processes such as protein synthesis [38-43]. These phage encode the genes responsible for many of the symptoms associated with the human disease. Until recently, most epidemiological and ecological studies of infectious diseases have focused on the presence and activity of the bacteria per se, neglecting the potentially significant role of the phage that carry the exotoxin genes and their role in transmitting these virulence traits [44-47].

Sequence analysis of several environmental metagenomes has shown that phage carrying exotoxin genes are common in the environment, however 16S rDNA analysis of metagenomes from the same environmental samples did not identify the cognate bacterial phage host [48]. A potential explanation of this finding is that phage in the environment may propagate in alternate bacterial hosts rather than those commonly associated with the human disease. The classic textbook description of phage-bacteria interactions implies that phage infection is limited to a specific host. However, as the ecology and physiology of phages has been further investigated, it is clear that some phage can infect multiple 


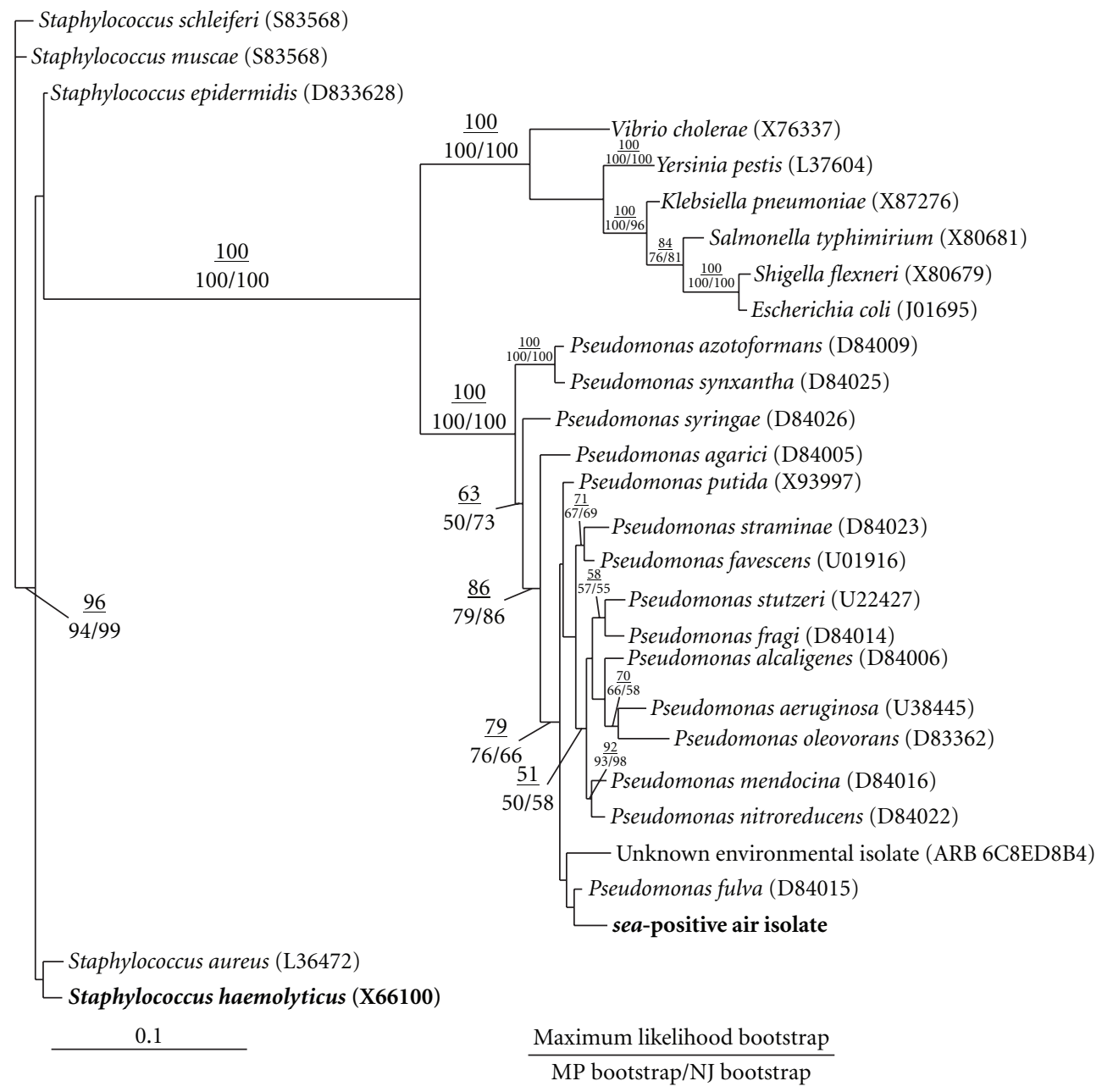

FIgURE 1: Phylogenetic tree of sea-positive isolate, its nearest relatives, and select outgroups. PAUP* was used to generate a consensus phylogenetic tree. Maximum Likelihood (ML) analysis was performed using 100 replicates with 10 random addition sequences searches per replicate. Maximum Parsimony (MP) analysis was performed using searches on 100 bootstrap replicated datasets with 10 search replicates. The Neighbor-joining (NJ) bootstrap analysis was performed with 1000 replicates. The (ML bootstrap)/(MP bootstrap/NJ bootstrap) values are as indicated. The sea-positive isolate is highlighted in bold and GenBank Accession numbers of each organism are in parentheses.

bacterial hosts [23, 49-73]. Examples of phage that carry exotoxin genes and can infect alternative hosts include $c t x \phi$ (infects both Vibrio cholerae and Vibrio mimicus [74]), stx2 phage (infects E. coli and Enterobacter cloacae [75]), and Botulinum toxin E phage (infects Clostridium botulinum and Clostridium butyricum [76]).

The mechanisms phage have developed to allow infection of a range of hosts are varied. Phage T2 and phage Mu alter their tail fibers to allow infection of alternative hosts $[77,78]$. Bordetella phage carry diversity generating retroelements that allow the phage to infect bacteria with different cell surface receptors and physiology [79]. Some phage can inactivate or recombine with endogenous lysogens to alter their host range $[45,80,81]$. Inter- and intraspecies examples of phage showing a larger infection range than previously believed have been demonstrated through experimentation with lab strains $[52,62,65,67,71,72,82-87]$.
Infection of alternative hosts in nature has also been demonstrated. Phage isolated from natural marine environments have been shown to subtly influence the composition of the bacterial community of those same environments [88]. Conversely, phage populations from various natural environments such as soil, lake water, and marine sediments have been shown to replicate when incubated with microbes from a different marine environment [6]. Comparison of the distribution of phage types in particular environments with the types of bacteria found in that same environment suggests that phage with quite broad host ranges must exist in nature [89]. Additionally, analyses of uncultured environmental phage libraries have revealed an abundance of mobile elements and genes involved in the mobilization of DNA [90-92]. Altogether these results suggest that phage are capable of infecting different hosts in the environment, providing a major mechanism for the spread of genes 
S. aureus strain MSSA476 sea gene S. aureus subsp. aureus MW2 sea gene S. aureus subsp. aureus Mu50 sea gene $S$. aureus subsp. aureus Mus sea gene S. aureus subsp. aureus Newman strain sea gene S. aureus subsp. aureus strain MRSA252 sea gen $S$. aureus strain FRI281 sea gene

S. aureus strain ATCC 13565 sea gene

S. aureus strain ATCC 25923 sea gene

S. aureus phage $\phi \mathrm{NM} 3$ sea gene

$S$. aureus strain FRI337 sea gene

Ambient environment isolate sea gene

S.aureus strain MSSA476 sea gene S. aureus subsp. aureus MW2 sea gene

$S$. aureus subsp. aureus Mu50 sea gene

$S$. aureus subsp. aureus Mu3 sea gene

S. aureus subsp. aureus Newrinan str.

S. aureus subsp. aureus strain MRSA252 sea gene

S. aureus strain FRI281 sea gene

S. aureus strain ATCC 13565 sea gene

S. aureus strain ATCC 25923 sea gene

S. aureus phage $\phi \mathrm{NM} 3$ sea gene

S. aureus strain FRI337 sea gene

Ambient environment isolate sea gene

S. aureus strain MSSA476 sea gene

S. aureus subsp. aureus MW2 sea gene

S. aureus subsp. aureus Mu50 sea gene

$S$. aureus subsp. aureus $\mathrm{Mu} 3$ sea gene

S. aureus subsp. aureus Newman strain sea gene

S. aureus subsp. aureus strain MRSA252 sea gene

S. aureus strain FRI281 sea gene

S. aureus strain ATCC 13565 sea gene

S. aureus strain ATCC 25923 sea gene

$S$. aureus phage $\phi \mathrm{NM} 3$ sea gene

$S$. aureus strain FRI337 sea gene

Ambient environment isolate sea gene

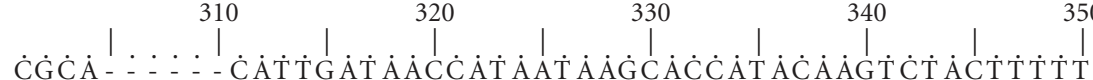
CGCA - . - - CAT TGAT AACCATAAT AAGCACCAT ACAAGTCT ACT T T T T CGCA - . - - CAT TGAT AACCATAAT AAGCACCAT ACAAGTCT ACT T T TT CGCA - . - . - CATTGATAACCATAATAAGCACCAT ACAAGTCTACT T T T T CGCA - - - - CAT TGATAACCATAATAAGCACCAT AT AAGTCT ACT T TTT CGCA - - - . CATTGAT AACCAT AAT AAGCACCAT AT AAGTCT ACT TT T T CAAAGG AT ATTGT TGAT AAAT AT AAAGGGAAAAAAGT AG ACT TGT ATGGT CAAAGG AT AT TGT TGAT AAAT AT AAAGGGAAAAAAGT AGACT TGT ATGGT CAAAGG AT AT TGT TG AT A A AT AT A A AGGG A A A A A AGT AG ACT T AT ATGGT CAAAGG AT AT TGT TGAT AAAT AT AAAGGGAAAAAAGT AG ACT T AT ATGGT CAAAGG AT AT TGT TGAT AAAT AT AAAGGGAAAAAAGT AG ACT T AT ATGGT CAAAGGAT AT TGT TGAT AAAT AT AAAGGGAAAAAAGT AGACT T AT ATGGT

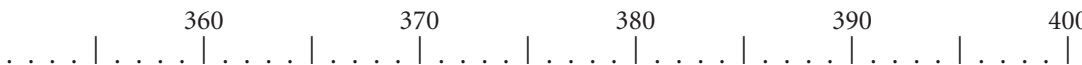

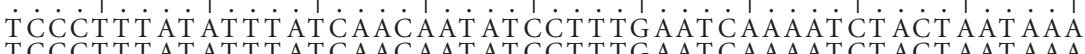
TCCCTTT AT AT T T ATCAACAAT AT CCT TTGAATCAAAATCT ACT AAT AAA TCCCT T T AT AT T T ATCAACAAT ATCCTTTGAATCAAAATCT ACT AAT AAA TCCCT T TATATTT ATCAACAAT AT CCT TTGAATCAAAATCT ACT AATAAA GCTT ATTATGGTT ATCAATG - - - - TGCGGGTGGT ACACCA - - AACAAA GCT T ATTATGGTT ATCAATG - - - - TGCGGGTGGT ACACCA - - AACAAA GCT TAT TATGGT T ATCAATG - . - . - TGCGGGTGGT ACACCA - - AACAAA GCT T ATT ATGGT T ATCAATG - . - . - TGCGGGTGGT ACACCA - - AACAAA

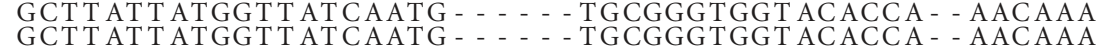
\begin{tabular}{c|c|c|c|c|}
410 & 420 & 430 & 400
\end{tabular}

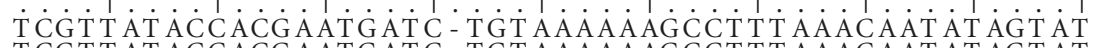
TCGTT AT ACCACGAATGATC - TGTAAAAAAGCCT TTAAACAAT AT AGTAT TCGT T AT ACCACG AATGATC - TGT AAAAAAGCCT TT AAACAAT AT AGT AT TCGT T AT ACCACGAATGATC - TGT AAAAAAGCCT TT AAACAAT AT AGT AT TCGTTAT ACCATGAATGAT T - TGT AAAAAAGCCT TT AAACAAT AT AGT AT TCGTTAT ACCATGAATGAT T - TGTAAAAAAGCCT T TAAACAAT AT AGT AT ACAGCTTGT - ATGT ATGGTGGTGT AACGTT ACATGAT AAT AATCG AT TG A ACAGCTTGT - ATGT ATGGTGGTGTAACGTT ACATGAT AAT AATCGATTGA ACAGCTTGC - ATGT ATGGTGGTGT AACGTT ACATGAT AAT AATCGATTGA ACAGCTTGC - ATGT ATGGTGGTGT AACGTT ACATGAT AAT AATCGATTGA ACAGCT TGC - ATGT ATGGTGGTGT AACGT T ACATGAT AAT AATCGATTGA ACAGCTTGC - ATGT ATGGTGGTGT AACGTT ACATGAT AAT AATCAATTGG

FIGURE 2: ClustalX2 alignment of top BLASTN hits of the sea gene from the ambient environmental isolate. The sea PCR product amplified from the cultured ambient air isolate was verified against the GenBank nonredundant database. The FASTA files of the top hits were downloaded and aligned using ClustalX2. The Accession number for the sea-related gene is HQ698309.

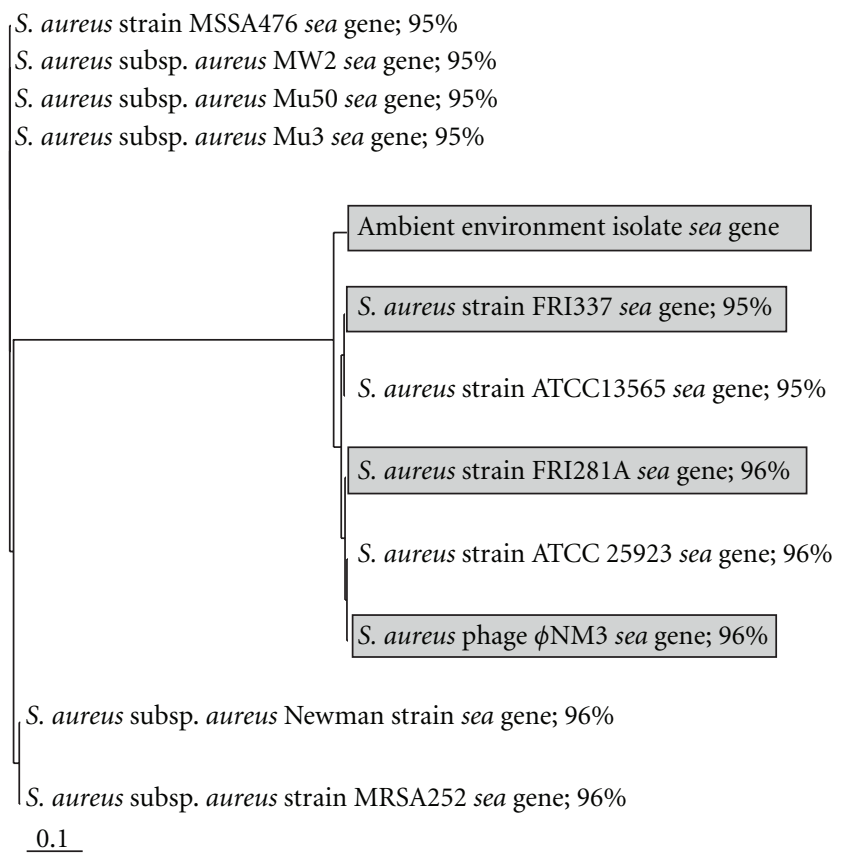

FIGURE 3: ClustalX2 guide tree of the top BLASTN hits of the sea gene from the ambient environmental isolate. The ambient air isolate is highlighted by a gray box along with $S$. aureus strains FRI337 and FRI281A (Food Research Institute) because the positive control used for sea exotoxin PCR comes from S. aureus strain FRI913. Percent identities are indicated beside the organism name as listed in GenBank. The GenBank Accession number for the sea-related gene is HQ698309. 


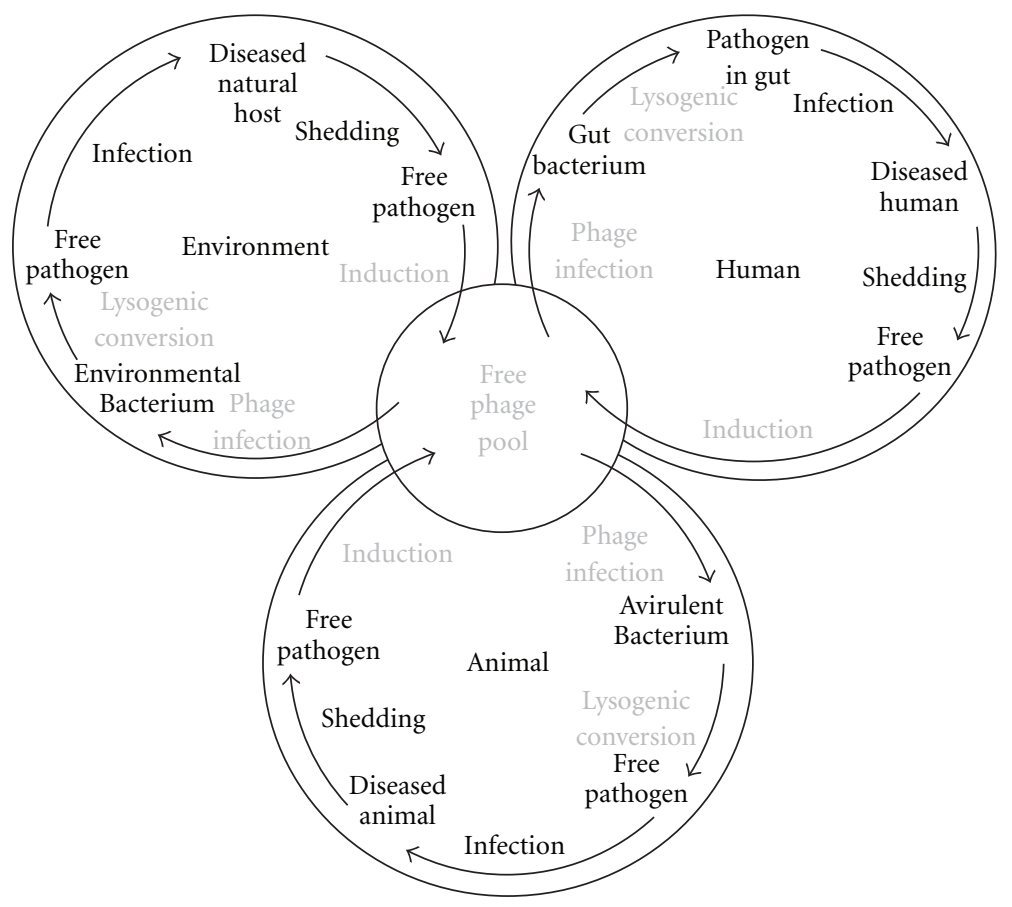

FIGURE 4: Free phage pool of exotoxin genes. Proposed scenarios for how exotoxin-encoding phage might be maintained in the environment and produce human pathogens through genetic exchange between the free phage pool and the natural, human, and animal environments. Light grey writing indicates phage/host interaction and potential for horizontal gene transfer.

between bacteria. Thus, phage may promote promiscuous horizontal gene transfer in nature.

This report provides the first direct evidence that alternative microbial hosts can carry exotoxin genes. The environmental isolate cultivated from outdoor ambient air was confirmed to carry the sea exotoxin gene by repeated exotoxin-specific PCR, and by sequencing and alignment of the sea-specific PCR product. The sea-specific PCR product was $95-96 \%$ identical at the nucleotide level to known sea genes in the GenBank nonredundant database.

When characterized microbiologically, the cultivated environmental isolate did not share the same characteristics as the control S. aureus FRI913 strain known to carry the sea gene. It did not grow on Staphylococcus enrichment media, nor did it share the same Gram staining properties as the $S$. aureus FRI913 strain (the environmental isolate was a Gram negative rod versus Staphylococcus which are Gram positive cocci). These results suggested that the sea gene was present in an alternative environmental host.

Further support for this conclusion was provided by sequencing of the $16 \mathrm{~S}$ rDNA from the cultivated environmental isolate. Alignment of the $16 \mathrm{~S}$ rDNA sequence from this isolate with the ARB database indicated the isolate was a Pseudomonas spp. and did not group with $S$. aureus. Moreover, phylogenetic analyses using PAUP* indicated that the isolate was related to Pseudomonas spp, not $S$. aureus. The ML, MP, and NJ bootstrap values of the main branches of the consensus tree that group the isolate with Pseudomonas spp. were $\geq 94$, indicating high probability that these branches are robust. This provides robust statistical evidence that the isolate is a Pseudomonas spp. Further evidence supporting this identification of the ambient air isolate was its relatively high G + C content (52.36\%) like many Pseudomonas spp., as compared to the low $\mathrm{G}+\mathrm{C}$ content of S. aureus (32.8\%).

We were unable to induce a sea positive phage by treatment from the environmental isolate via mitomycin $\mathrm{C}$ treatment [81]. There are at least two possible explanations why the environmental isolate was carrying the sea-related gene, but did not produce phage. First, generalized transduction could have transferred a region of bacterial chromosomal DNA containing the sea gene into the Pseudomonas spp. without integration of the phage itself [93]. Second, it is possible that the exotoxin was transferred via a phage, but the phage genes were subsequently mutated due to selection against harmful phage genes in the lysogen [94-102].

Based on the examples from the literature and the data generated from this study, we propose the following model for transfer of phage-encoded exotoxin genes to a novel bacterium leading to the creation of a new human pathogen. A "free phage pool" (Figure 4) can potentially lead to new disease outbreaks in three ways: (i) transduction of exotoxin genes to an environmental bacterium that subsequently infects a human; (ii) transduction of exotoxin genes from the environmental reservoir to a bacterium in the normal human microbiota; (iii) transduction of a bacterium associated with a nonhuman animal, with subsequent infection of a human. In all three scenarios, once the phage is propagated within the alternate bacterial hosts it can lyse the host and re-enter the "free-phage pool" ready to transduce the exotoxin genes to other bacteria. In this manner, the genes are maintained in 
the environment independent of the bacterial host typically involved in the human disease.

The evidence that there is an environmental reservoir of exotoxin genes in bacteria that are not normally associated with human disease, suggests the possibility that novel diseases may evolve through horizontal transfer of virulence genes via transduction to new microbial hosts (Figure 4).

\section{Materials and Methods}

4.1. Sampling of Indoor and Outdoor Air. To collect bacterial air isolates, Luria Bertani (LB) agar plates containing $50 \mathrm{mg}$ of cyclohexamide to prevent growth of fungi, were exposed to ambient air. These plates were then incubated at room temperature for $48-72 \mathrm{hr}$. All isolates that grew on the LB plates conditions were then subcultured into sterile 96-well plates containing LB and 15\% glycerol. These subcultured isolates were grown, with aeration, at room temperature for 48-72 hr then stored at $4^{\circ} \mathrm{C}$ until screened by PCR.

4.2. PCR Assays and Sequencing. A colony PCR assay was used to initially screen for the Staphylococcus enterotoxin A (sea) gene. The sea-specific PCR primers amplified a $498 \mathrm{bp}$ partial sequence within the coding region of the sea gene. The sea primers were (forward primer) $5^{\prime}$ GCAGGGAACAGCTTTAGGC-3' and (reverse primer) $5^{\prime}$-GTTCTGTAGAAGTATGAAACACG-3'. To identify the bacterial isolate carrying the sea gene, a $16 \mathrm{~S}$ rDNA PCR assay was used and the resulting PCR product sequenced. The primers used for the $16 \mathrm{~S}$ rDNA PCR were (forward) 5'-AGAGTTTGATCMTGGCTCAG-3' and (reverse) $5^{\prime}$ TACGGYTACCTTGTTACGACTT- ${ }^{\prime}$. Five microliters of the subcultured isolates suspension was used as a template in the sea-specific PCR16S rDNA PCR. The PCR thermocycling conditions for the sea-specific PCR and 16S rDNA PCR were as described previously [103]. To control against possible PCR contamination of the environmental sample DNAs, all PCRs were performed in a completely separate room and different building with different air handling systems. The PCR products were run on a $1 \%$ agarose gel at $150 \mathrm{~V}$. Sequencing of the sea-specific PCR and 16S rDNA PCR products was performed at the SDSU Microchemical Core Facility. To confirm the sea PCR product was the target gene, a BLASTN alignment of the PCR product was performed against the nonredundant GenBank database [104]. The top 12 hits were then aligned and a tree generated using ClustalX2 [36].

\subsection{Microbiological Characterization of Environmental Isolate.} The air isolate carrying the sea-like gene was characterized by plating onto Staph 110 media [105], a media that enriches for Staphylococcus aureus, and LB medium. The plates were incubated at room temperature and at $35^{\circ} \mathrm{C}$. A Gram stain was also performed on the isolate identified as sea-positive by colony PCR.

4.4. Molecular Characterization of Environmental Isolate. Phylogenetic analyses were performed on the 16S rDNA
PCR product sequence to molecularly identify the ambient air isolate. An alignment with the ARB 16S rDNA database was used to identify the nearest relatives to the ambient air isolate for use in creating a phylogenetic tree in PAUP* [33]. Maximum Likelihood (ML) was implemented in PAUP* to build the highest likelihood tree under an HKY85 model of sequence evolution with estimated nucleotide frequencies, shape parameter, and number of invariant sites. The heuristic search approach to find the best ML tree included 100 random addition sequence searches using TBR branch swapping. The ML bootstrap involved 100 replicates with 10 random addition sequences searches per replicate. The best Maximum Parsimony (MP) tree was found through a random addition sequence heuristic search strategy with 100 replicates. The maximum number of trees kept during each search was capped at 1000. MP bootstrap analyses were performed using searches on 100 bootstrap replicated datasets using the same heuristic search strategy except with 10, rather than 100, search replicates. The Neighbor-joining (NJ) bootstrap analysis was performed with 1000 replicates.

\section{Acknowledgments}

V. Casas was supported by an NIH/NIGMS Minority Biomedical Research Support Fellowship (5R25-GM8907). This work was supported in part by grant U54CA132384 from the National Cancer Institute. The authors thank Dr. Joan Chen and the SDSU Microchemical Core Facility for DNA sequencing.

\section{References}

[1] D. P. Falcao, "Bacterial enteropathogens: general characteristics," Revista de Ciencias Farmaceuticas, vol. 17, pp. 25-55, 1996.

[2] S. Leppla, "The anthrax toxin complex," in Sourcebook of Bacterial Protein Toxins, J. Alouf and J. Freer, Eds., pp. 277298, Academic Press, New York, NY, USA, 1991.

[3] M. Pittman, "The concept of pertussis as a toxin-mediated disease," Pediatric Infectious Disease, vol. 3, no. 5, pp. 467486, 1984.

[4] M. Muniesa, F. Lucena, and J. Jofre, "Comparative survival of free Shiga toxin 2-encoding phages and Escherichia coli strains outside the gut," Applied and Environmental Microbiology, vol. 65, no. 12, pp. 5615-5618, 1999.

[5] R. Dumke, U. Schröter-Bobsin, E. Jacobs, and I. Röske, "Detection of phages carrying the Shiga toxin 1 and 2 genes in waste water and river water samples," Letters in Applied Microbiology, vol. 42, no. 1, pp. 48-53, 2006.

[6] E. Sano, S. Carlson, L. Wegley, and F. Rohwer, "Movement of viruses between biomes," Applied and Environmental Microbiology, vol. 70, no. 10, pp. 5842-5846, 2004.

[7] G. S. Johannessen, C. E. James, H. E. Allison, D. L. Smith, J. R. Saunders, and A. J. McCarthy, "Survival of a Shiga toxin-encoding bacteriophage in a compost model," FEMS Microbiology Letters, vol. 245, no. 2, pp. 369-375, 2005.

[8] A. Aertsen, D. Faster, and C. W. Michiels, "Induction of Shiga toxin-converting prophage in Escherichia coli by high hydrostatic pressure," Applied and Environmental Microbiology, vol. 71, no. 3, pp. 1155-1162, 2005. 
[9] L. Mocé-Llivina, M. Muniesa, H. Pimenta-Vale, F. Lucena, and J. Jofre, "Survival of bacterial indicator species and bacteriophages after thermal treatment of sludge and sewage," Applied and Environmental Microbiology, vol. 69, no. 3, pp. 1452-1456, 2003.

[10] S. C. Jiang and J. H. Paul, "Gene transfer by transduction in the marine environment," Applied and Environmental Microbiology, vol. 64, no. 8, pp. 2780-2787, 1998.

[11] T. Hidaka and T. Fujimura, "On the heat- and chloroformresistance of marine bacteriophages," Memoirs of the Faculty of Fisheries, Kagoshima University, vol. 20, pp. 155-158, 1971.

[12] H. Brüssow, C. Canchaya, and W. D. Hardt, "Phages and the evolution of bacterial pathogens: from genomic rearrangements to lysogenic conversion," Microbiology and Molecular Biology Reviews, vol. 68, no. 3, pp. 560-602, 2004.

[13] H.-W. Ackermann and M. S. DuBow, Viruses of Prokaryotes; Volume I: General Properties of Bacteriophages, CRC Press, Boca Raton, Fla, USA, 1987.

[14] V. J. Freeman, "Studies on the virulence of bacteriophageinfected strains of Corynebacterium diphtheriae," Journal of bacteriology, vol. 61, no. 6, pp. 675-688, 1951.

[15] N. B. Groman, "The relation of bacteriophage to the change of Corynebacterium diphtheriae from avirulence to virulence," Science, vol. 117, no. 3038, pp. 297-299, 1953.

[16] M. K. Waldor and J. J. Mekalanos, "Lysogenic conversion by a filamentous phage encoding cholera toxin,” Science, vol. 272, no. 5270, pp. 1910-1913, 1996.

[17] D. W. K. Acheson, J. Reidl, X. Zhang, G. T. Keusch, J. J. Mekalanos, and M. K. Waldor, "In vivo transduction with shiga toxin 1-encoding phage," Infection and Immunity, vol. 66, no. 9, pp. 4496-4498, 1998.

[18] R. Novick, "Properties of a cryptic high-frequency transducing phage in Staphylococcus aureus," Virology, vol. 33, no. 1, pp. 155-166, 1967.

[19] M. J. Betley and J. J. Mekalanos, "Staphylococcal enterotoxin A is encoded by phage," Science, vol. 229, no. 4709, pp. 185-187, 1985.

[20] D. C. Coleman, D. J. Sullivan, R. J. Russell, J. P. Arbuthnott, B. F. Carey, and H. M. Pomeroy, "Staphylococcus aureus bacteriophages mediating the simulataneous lysogenic conversion of $\beta$-lysin, staphylokinase and enterotoxin A: molecular mechanism of triple conversion," Journal of General Microbiology, vol. 135, no. 6, pp. 1679-1697, 1989.

[21] M. J. Betley, S. Lofdahl, and B. N. Kreiswirth, "Staphylococcal enterotoxin A gene is associated with a variable genetic element," Proceedings of the National Academy of Sciences of the United States of America, vol. 81, no. 16 I, pp. 5179-5183, 1984.

[22] P. Holochová, V. Růžičková, R. Pantůček, P. Petráš, R. Janisch, and J. Doškař, "Genomic diversity of two lineages of exfoliative toxin A-converting phages predominating in Staphylococcus aureus strains in the Czech Republic," Research in Microbiology, vol. 161, no. 4, pp. 260-267, 2010.

[23] H. Hoshiba, J. Uchiyama, S. I. Kato et al., "Isolation and characterization of a novel Staphylococcus aureus bacteriophage, $\phi \mathrm{MR} 25$, and its therapeutic potential," Archives of Virology, vol. 155, no. 4, pp. 545-552, 2010.

[24] J. D. Carroll, M. T. Cafferkey, and D. C. Coleman, "Serotype F double- and triple-converting phage insertionally inactivate the Staphylococcus aureus $\beta$-toxin determinant by a common molecular mechanism," FEMS Microbiology Letters, vol. 106, no. 2, pp. 147-155, 1993.

[25] T. Yamaguchi, T. Hayashi, H. Takami et al., "Phage conversion of exfoliative toxin A production in Staphylococcus aureus," Molecular Microbiology, vol. 38, no. 4, pp. 694-705, 2000.

[26] Y. Endo, T. Yamada, K. Matsunaga, Y. Hayakawa, T. Kaidoh, and S. Takeuchi, "Phage conversion of exfoliative toxin A in Staphylococcus aureus isolated from cows with mastitis," Veterinary Microbiology, vol. 96, no. 1, pp. 81-90, 2003.

[27] R. M. Dempsey, D. Carroll, H. Kong, L. Higgins, C. T. Keane, and D. C. Coleman, "Sau421, a Bcgl-like restrictionmodification system encoded by the Staphylococcus aureus quandruple-converting phage $\pi 42$," Microbiology, vol. 151, no. 4, pp. 1301-1311, 2005.

[28] C. Goerke, J. Koller, and C. Wolz, "Ciprofloxacin and trimethoprim cause phage induction and virulence modulation in Staphylococcus aureus," Antimicrobial Agents and Chemotherapy, vol. 50, no. 1, pp. 171-177, 2006.

[29] W. J. B. van Wamel, S. H. M. Rooijakkers, M. Ruyken, K. P. M. van Kessel, and J. A. G. van Strijp, "The innate immune modulators staphylococcal complement inhibitor and chemotaxis inhibitory protein of Staphylococcus aureus are located on $\beta$-hemolysin-converting bacteriophages," Journal of Bacteriology, vol. 188, no. 4, pp. 1310-1315, 2006.

[30] R. Kumagai, K. Nakatani, N. Ikeya, Y. Kito, T. Kaidoh, and S. Takeuchi, "Quadruple or quintuple conversion of hlb, sak, sea (or sep), scn, and chp genes by bacteriophages in non$\beta$-hemolysin-producing bovine isolates of Staphylococcus aureus," Veterinary Microbiology, vol. 122, no. 1-2, pp. 190195, 2007.

[31] A. J. Synnott, Y. Kuang, M. Kurimoto, K. Yamamichi, H. Iwano, and Y. Tanji, "Isolation from sewage influent and characterization of novel Staphylococcus aureus bacteriophages with wide host ranges and potent lytic capabilities," Applied and Environmental Microbiology, vol. 75, no. 13, pp. 4483-4490, 2009.

[32] Difco, Difco Manual, Difco Laboratories, Detroit, Mich, USA, 10th edition, 1984.

[33] D. Swofford, PAUP*: Phylogenetic Analysis Using Parsimony (* and other methods) 4.0 Beta, Sinauer Associates, Sunderland, Mass, USA, 4.0 Beta edition, 2002.

[34] T. A. Hall, "BioEdit: a user-friendly biological sequence alignment editor and analysis program for Windows 95/98/NT," Nucleic Acids Symposium Series, vol. 41, pp. 95-98, 1999.

[35] J. D. Thompson, D. G. Higgins, and T. J. Gibson, "CLUSTAL $\mathrm{W}$ : improving the sensitivity of progressive multiple sequence alignment through sequence weighting, position-specific gap penalties and weight matrix choice," Nucleic Acids Research, vol. 22, no. 22, pp. 4673-4680, 1994.

[36] J. D. Thompson, T. J. Gibson, F. Plewniak, F. Jeanmougin, and D. G. Higgins, "The CLUSTAL X windows interface: flexible strategies for multiple sequence alignment aided by quality analysis tools," Nucleic Acids Research, vol. 25, no. 24, pp. 4876-4882, 1997.

[37] R. Overbeek, T. Begley, R. M. Butler et al., "The subsystems approach to genome annotation and its use in the project to annotate 1000 genomes," Nucleic Acids Research, vol. 33, no. 17, pp. 5691-5702, 2005.

[38] K. Sandvig, O Garred, and B. van Deurs, "Intracellular transport and processing of protein toxins produced by enteric bacteria," Advances in Experimental Medicine and Biology, vol. 412, pp. 225-232, 1997.

[39] G. M. Vath, C. A. Earhart, J. V. Rago et al., "The structure of the superantigen exfoliative toxin a suggests a novel regulation as a serine protease," Biochemistry, vol. 36, no. 7, pp. 1564-1566, 1997. 
[40] B. M. Davis and M. K. Waldor, "Mobile genetic elements and bacteria pathogenesis," in Mobile DNA II, N. L. Craig, R. Gragie, M. Gellert, and A. M. Lambowitz, Eds., pp. 10401055, ASM Press, Washington, DC, USA, 2002.

[41] C. A. Mims, Mims' Pathogenesis of Infectious Disease, Academic Press, San Diego, Calif, USA, 4th edition, 1995.

[42] W. Ziebuhr, K. Ohlsen, H. Karch, T. Korhonen, and J. Hacker, "Evolution of bacterial pathogenesis," Cellular and Molecular Life Sciences, vol. 56, no. 9-10, pp. 719-728, 1999.

[43] A. A. Salyers and D. D. Whitt, Bacterial Pathogenesis: A Molecular Approach, ASM Press, Washington, DC, USA, 2002.

[44] S. M. Faruque, I. B. Naser, M. J. Islam et al., "Seasonal epidemics of cholera inversely correlate with the prevalence of environmental cholera phages," Proceedings of the National Academy of Sciences of the United States of America, vol. 102, no. 5, pp. 1702-1707, 2005.

[45] R. K. Aziz, R. A. Edwards, W. W. Taylor, D. E. Low, A. McGeer, and M. Kotb, "Mosaic prophages with horizontally acquired genes account for the emergence and diversification of the globally disseminated M1t1 clone of Streptococcus pyogenes," Journal of Bacteriology, vol. 187, no. 10, pp. 3311-3318, 2005.

[46] R. L. Shapiro, C. Hatheway, and D. L. Swerdlow, "Botulism in the United States: a clinical and epidemiologic review," Annals of Internal Medicine, vol. 129, no. 3, pp. 221-228, 1998.

[47] S. M. Faruque, S. K. Roy, A. R. M. A. Alim, A. K. Siddique, and M. J. Albert, "Molecular epidemiology of toxigenic Vibrio cholerae in Bangladesh studied by numerical analysis of rRNA gene restriction patterns," Journal of Clinical Microbiology, vol. 33, no. 11, pp. 2833-2838, 1995.

[48] V. Casas and F. Rohwer, "Phage metagenomics," Methods in Enzymology, vol. 421, pp. 259-268, 2007.

[49] J. A. Baross, J. Liston, and R. Y. Morita, "Ecological relationship between Vibrio parahaemolyticus and agardigesting vibrios as evidenced by bacteriophage susceptibility patterns," Applied and Environmental Microbiology, vol. 36, no. 3, pp. 500-505, 1978.

[50] J. P. Bollback and J. P. Huelsenbeck, "Phylogeny, genome evolution, and host specificity of single-stranded RNA bacteriophage (family Leviviridae)," Journal of Molecular Evolution, vol. 52, no. 2, pp. 117-128, 2001.

[51] C. Dini and P. J. De Urraza, "Isolation and selection of coliphages as potential biocontrol agents of enterohemorrhagic and Shiga toxin-producing E. coli(EHEC and STEC) in cattle," Journal of Applied Microbiology, vol. 109, no. 3, pp. 873-887, 2010.

[52] T. Koga, S. Toyoshima, and T. Kawata, "Morphological varieties and host ranges of Vibrio parahaemolyticus bacteriophages isolated from seawater," Applied and Environmental Microbiology, vol. 44, no. 2, pp. 466-470, 1982.

[53] M. L. Saxelin, E. L. Nurmiaho, M. P. Korhola, and V. Sundman, "Partial characterization of a new C3-type capsuledissolving phage of Streptococcus cremoris," Canadian Journal of Microbiology, vol. 25, no. 10, pp. 1182-1187, 1979.

[54] R. H. Olsen, J. S. Siak, and R. H. Gray, "Characteristics of PRD1, a plasmid dependent broad host range DNA bacteriophage," Journal of Virology, vol. 14, no. 3, pp. 689699, 1974.

[55] J. T. Douglas and S. S. Elberg, "Isolation of Brucella melitensis phage of broad biotype and species specificity," Infection and Immunity, vol. 14, no. 1, pp. 306-308, 1976.

[56] D. E. Bradley, J. N. Coetzee, T. Bothma, and R. W. Hedges, "Phage X: a plasmid-dependent, broad host range, filamen- tous bacterial virus," Journal of General Microbiology, vol. 126, no. 2, pp. 389-396, 1981.

[57] J. Anne, W. Wohlleben, and H. J. Burkardt, "Morphological and molecular characterization of several actinophages isolated from soil which lyse Streptomyces cattleya or $S$. Venezuelae," Journal of General Microbiology, vol. 130, no. 10, pp. 2639-2649, 1984.

[58] J. Hantula, A. Kurki, P. Vuoriranta, and D. H. Bamford, "Ecology of bacteriophages infecting activated sludge bacteria," Applied and Environmental Microbiology, vol. 57, no. 8, pp. 2147-2151, 1991.

[59] S. Matsuzaki, S. Tanaka, T. Koga, and T. Kawata, "A broadhost-range vibriophage, KVP40, isolated from sea water," Microbiology and Immunology, vol. 36, no. 1, pp. 93-97, 1992.

[60] J. Nolling, A. Groffen, and W. M. De Vos, “ФF1 and $Ф F 3$, two novel virulent, archaeal phages infecting different thermophilic strains of the genus Methanobacterium," Journal of General Microbiology, vol. 139, no. 10, pp. 2511-2516, 1993.

[61] D. H. Bamford, J. Caldentey, and J. K. Bamford, "Bacteriophage PRD1: a broad host range dsDNA tectivirus with an internal membrane," Advances in Virus Research, vol. 45, pp. 281-319, 1995.

[62] E. C. Jensen, H. S. Schrader, B. Rieland et al., "Prevalence of broad-host-range lytic bacteriophages of Sphaerotilus natans, Escherichia coli, and Pseudomonas aeruginosa," Applied and Environmental Microbiology, vol. 64, no. 2, pp. 575-580, 1998.

[63] A. O. Kiliç, S. I. Pavlova, S. Alpay, S. S. Kiliç, and L. Tao, "Comparative study of vaginal Lactobacillus phages isolated from women in the United States and Turkey: prevalence, morphology, host range, and DNA homology," Clinical and Diagnostic Laboratory Immunology, vol. 8, no. 1, pp. 31-39, 2001.

[64] M. A. Khan, H. Satoh, H. Katayama, F. Kurisu, and T. Mino, "Bacteriophages isolated from activated sludge processes and their polyvalency," Water Research, vol. 36, no. 13, pp. 33643370, 2002.

[65] A. Beumer and J. B. Robinson, "A broad-host-range, generalized transducing phage (SN-T) acquires 16S rRNA genes from different genera of bacteria," Applied and Environmental Microbiology, vol. 71, no. 12, pp. 8301-8304, 2005.

[66] Y. Xu, D. R. Peng, H. Y. Xiong et al., "Study on the nucleic acid of E. coli bacteriophage with broad host range and its sterilization effect to sewage samples from the environment," Zhonghua Liu Xing Bing Xue Za Zhi, vol. 26, no. 5, pp. 356360, 2005.

[67] T. M. Ruokoranta, A. M. Grahn, J. J. Ravantti, M. M. Poranen, and D. H. Bamford, "Complete genome sequence of the broad host range single-stranded RNA phage PRR1 places it in the levivirus genus with characteristics shared with alloleviviruses," Journal of Virology, vol. 80, no. 18, pp. 9326-9330, 2006.

[68] L. Deng and P. K. Hayes, "Evidence for cyanophages active against bloom-forming freshwater cyanobacteria," Freshwater Biology, vol. 53, no. 6, pp. 1240-1252, 2008.

[69] D. Schwudke, A. Ergin, K. Michael et al., "Broad-hostrange Yersinia phage PY100: genome sequence, proteome analysis of virions, and DNA packaging strategy," Journal of Bacteriology, vol. 190, no. 1, pp. 332-342, 2008.

[70] J. Uchiyama, M. Rashel, Y. Maeda et al., "Isolation and characterization of a novel Enterococcus faecalis bacteriophage $\varphi \mathrm{EF} 24 \mathrm{C}$ as a therapeutic candidate," FEMS Microbiology Letters, vol. 278, no. 2, pp. 200-206, 2008. 
[71] J. Dorscht, J. Klumpp, R. Bielmann et al., "Comparative genome analysis of Listeria bacteriophages reveals extensive mosaicism, programmed translational frameshifting, and a novel prophage insertion site," Journal of Bacteriology, vol. 191, no. 23, pp. 7206-7215, 2009.

[72] S. M. Lehman, A. M. Kropinski, A. J. Castle, and A. M. Svircev, "Complete genome of the broad-host-range Erwinia amylovora phage ФEa21-4 and its relationship to Salmonella phage Felix O1," Applied and Environmental Microbiology, vol. 75, no. 7, pp. 2139-2147, 2009.

[73] X. Qiao, Y. Sun, J. Qiao, F. Di Sanzo, and L. Mindich, "Characterization of $\Phi 2954$, a newly isolated bacteriophage containing three dsRNA genomic segments," BMC Microbiology, vol. 10, article 55, 2010.

[74] S. M. Faruque, M. M. Rahman, . Asadulghani, K. M. N. Islam, and J. J. Mekalanos, "Lysogenic conversion of environmental Vibrio mimicus strains by СТХФ," Infection and Immunity, vol. 67, no. 11, pp. 5723-5729, 1999.

[75] M. Mehrotra, G. Wang, and W. M. Johnson, "Multiplex PCR for detection of genes for Staphylococcus aureus enterotoxins, exfoliative toxins, toxic shock syndrome toxin 1, and methicillin resistance," Journal of Clinical Microbiology, vol. 38, no. 3, pp. 1032-1035, 2000.

[76] Y. Zhou, H. Sugiyama, and E. A. Johnson, "Transfer of neurotoxigenicity from Clostridium butyricum to a nontoxigenic Clostridium botulinum type E-like strain," Applied and Environmental Microbiology, vol. 59, no. 11, pp. 3825-3831, 1993.

[77] M. Yoichi, M. Abe, K. Miyanaga, H. Unno, and Y. Tanji, "Alteration of tail fiber protein gp38 enables T2 phage to infect Escherichia coli O157:H7," Journal of Biotechnology, vol. 115, no. 1, pp. 101-107, 2005.

[78] C. Koch, G. Mertens, F. Rudt et al., "The invertible G segment," in Phage Mu, N. Symonds, A. Toussaint, P. van de Putte, and M. Howe, Eds., pp. 75-91, Cold Spring Harbor Laboratory Press, Cold Spring Harbor, NY, USA, 1987.

[79] S. Doulatov, A. Hodes, L. Dal et al., "Tropism switching in Bordetella bacteriophage defines a family of diversitygenerating retroelements," Nature, vol. 431, no. 7007, pp. 476-481, 2004.

[80] M. M. Susskind, A. Wright, and D. Botstein, "Superinfection exclusion by P22 prophage in lysogens of Salmonella typhimurium. II. Genetic evidence for two exclusion systems," Virology, vol. 45, no. 3, pp. 638-652, 1971.

[81] S. Maloy, V. Stewart, and R. Taylor, Genetic Analysis of Pathogenic Bacteria: A Laboratory Manual, Cold Spring Harbor Laboratory Press, Cold Spring Harbor, NY, USA, 1996.

[82] M. L. Saxelin, E. L. Nurmiaholassila, V. T. Merilainen, and R. I. Forsen, "Ultrastructure and host specificity of bacteriophages of streptococcus-cremoris, streptococcus-lactis subsp diacetylactis, and leuconostoc-cremoris from Finnish fermented Milk Viili," Applied and Environmental Microbiology, vol. 52, pp. 771-777, 1986.

[83] C. M. Carvalho, B. W. Gannon, D. E. Halfhide et al., "The in vivo efficacy of two administration routes of a phage cocktail to reduce numbers of Campylobacter coli and Campylobacter jejuni in chickens," BMC Microbiology, vol. 10, article 232, 2010.

[84] T. Kenzaka, K. Tani, and M. Nasu, "High-frequency phagemediated gene transfer in freshwater environments determined at single-cell level," ISME Journal, vol. 4, no. 5, pp. 648-659, 2010.
[85] T. J. Evans, M. A. Crow, N. R. Williamson et al., "Characterization of a broad-host-range flagellum-dependent phage that mediates high-efficiency generalized transduction in, and between, Serratia and Pantoea," Microbiology, vol. 156, no. 1, pp. 240-247, 2010.

[86] K. Sau, S. K. Gupta, S. Sau, S. C. Mandal, and T. C. Ghosh, "Studies on synonymous codon and amino acid usage biases in the broad-host range bacteriophage KVP40," Journal of Microbiology, vol. 45, no. 1, pp. 58-63, 2007.

[87] M. Namura, T. Hijikata, K. Miyanaga, and Y. Tanji, “Detection of Escherichia coli with fluorescent labeled phages that have a broad host range to E. coli in sewage water," Biotechnology Progress, vol. 24, no. 2, pp. 481-486, 2008.

[88] J. A. Fuhrman and M. Schwalbach, "Viral influence on aquatic bacterial communities," Biological Bulletin, vol. 204, no. 2, pp. 192-195, 2003.

[89] M. Breitbart, J. H. Miyake, and F. Rohwer, "Global distribution of nearly identical phage-encoded DNA sequences," FEMS Microbiology Letters, vol. 236, no. 2, pp. 249-256, 2004.

[90] M. Breitbart, P. Salamon, B. Andresen et al., "Genomic analysis of uncultured marine viral communities," Proceedings of the National Academy of Sciences of the United States of America, vol. 99, no. 22, pp. 14250-14255, 2002.

[91] M. Breitbart, I. Hewson, B. Felts et al., "Metagenomic analyses of an uncultured viral community from human feces," Journal of Bacteriology, vol. 185, no. 20, pp. 6220-6223, 2003.

[92] M. Breitbart, L. Wegley, S. Leeds, T. Schoenfeld, and F. Rohwer, "Phage community dynamics in hot springs," Applied and Environmental Microbiology, vol. 70, no. 3, pp. 1633-1640, 2004.

[93] A. Thierauf, G. Perez, and A. S. Maloy, "Generalized transduction," Methods in Molecular Biology, vol. 501, pp. 267286, 2009.

[94] R. E. Lenski and B. R. Levin, "Constraints on the coevolution of bacteria and virulent phage: a model, some experiments, and predictions for natural communities," American Naturalist, vol. 125, no. 4, pp. 585-602, 1985.

[95] M. T. Horne, "Coevolution of Escherichia coli and bacteriophages in chemostat culture," Science, vol. 168, no. 3934, pp. 992-993, 1970.

[96] Y. Husimi, "Selection and evolution of bacteriophages in cellstat," Advances in Biophysics, vol. 25, no. C, pp. 1-43, 1989.

[97] E. A. Miao and S. I. Miller, "Bacteriophages in the evolution of pathogen-host interactions," Proceedings of the National Academy of Sciences of the United States of America, vol. 96, no. 17, pp. 9452-9454, 1999.

[98] H. Neve, K. I. Zenz, F. Desiere, A. Koch, K. J. Heller, and H. Brüssow, "Comparison of the lysogeny modules from the temperate Streptococcus thermophilus bacteriophages TPJ34 and Sfi21: implications for the modular theory of phage evolution," Virology, vol. 241, no. 1, pp. 61-72, 1998.

[99] R. W. Hendrix, M. C. M. Smith, R. N. Burns, M. E. Ford, and G. F. Hatfull, "Evolutionary relationships among diverse bacteriophages and prophages: all the world's a phage," Proceedings of the National Academy of Sciences of the United States of America, vol. 96, no. 5, pp. 2192-2197, 1999.

[100] M. A. Tormo-Más, I. Mir, A. Shrestha et al., "Moonlighting bacteriophage proteins derepress staphylococcal pathogenicity islands," Nature, vol. 465, no. 7299, pp. 779-782, 2010.

[101] L. A. Marraffini and E. J. Sontheimer, "CRISPR interference: RNA-directed adaptive immunity in bacteria and archaea," Nature Reviews Genetics, vol. 11, no. 3, pp. 181-190, 2010. 
[102] R. Gregory, V. A. Saunders, and J. R. Saunders, "Rule-based simulation of temperate bacteriophage infection: restrictionmodification as a limiter to infection in bacterial populations," BioSystems, vol. 100, no. 3, pp. 166-177, 2010.

[103] V. Casas, J. Miyake, H. Balsley et al., "Widespread occurrence of phage-encoded exotoxin genes in terrestrial and aquatic environments in Southern California," FEMS Microbiology Letters, vol. 261, no. 1, pp. 141-149, 2006.

[104] S. F. Altschul, W. Gish, W. Miller, E. W. Myers, and D. J. Lipman, "Basic local alignment search tool," Journal of Molecular Biology, vol. 215, no. 3, pp. 403-410, 1990.

[105] Difco Manual, Difco Laboratories, Detroit, Mich, USA, 10th edition, 1984. 

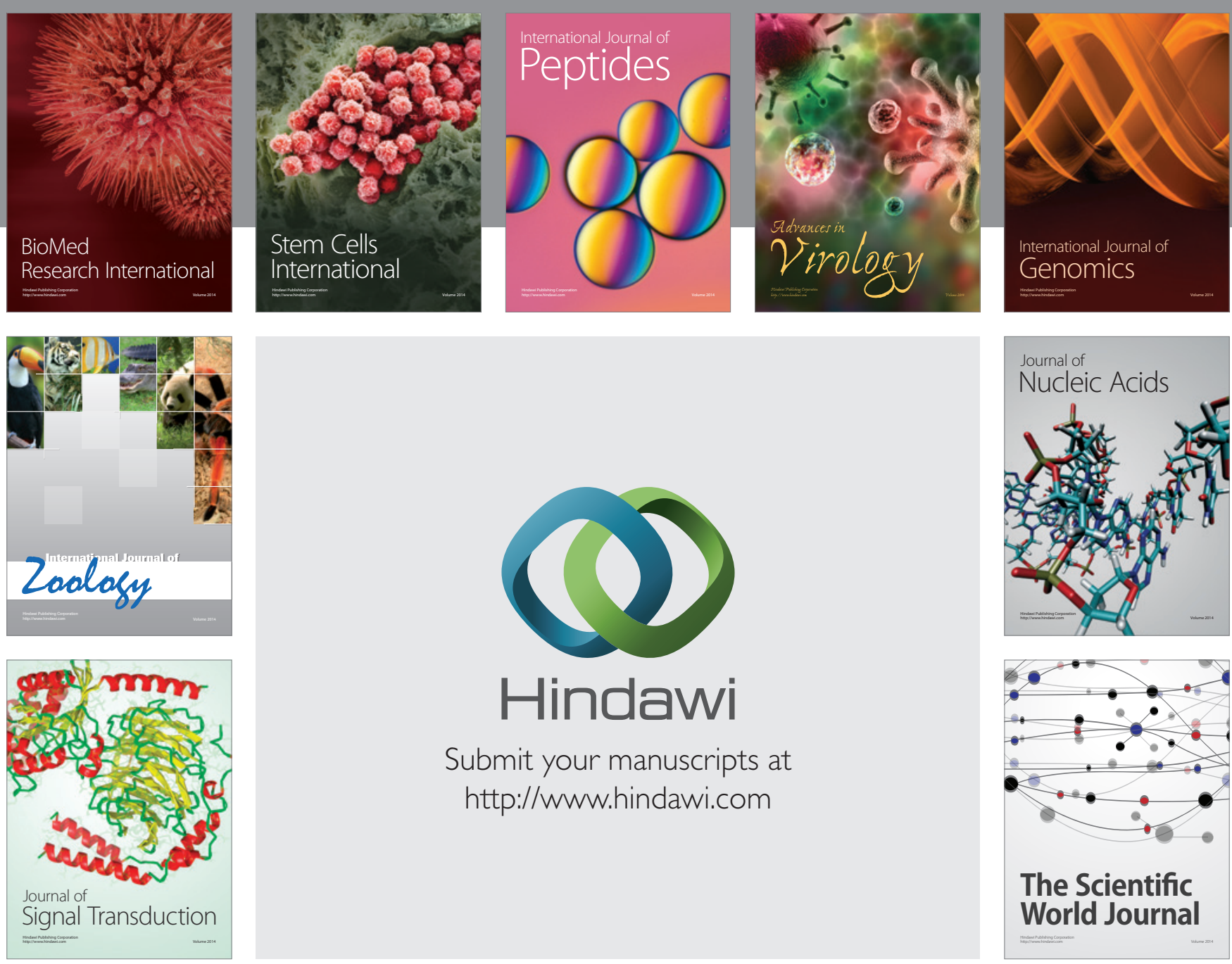

Submit your manuscripts at

http://www.hindawi.com
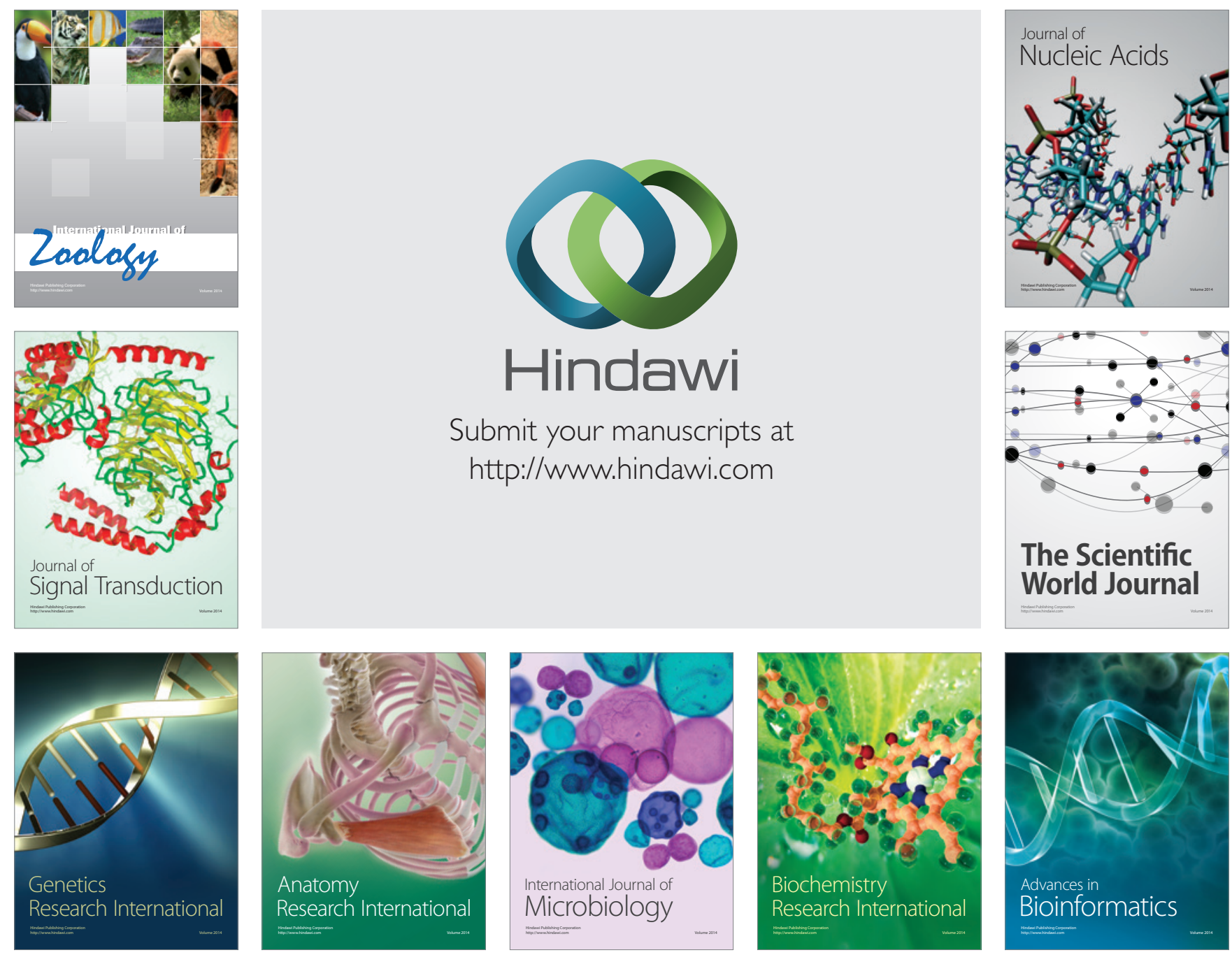

The Scientific World Journal
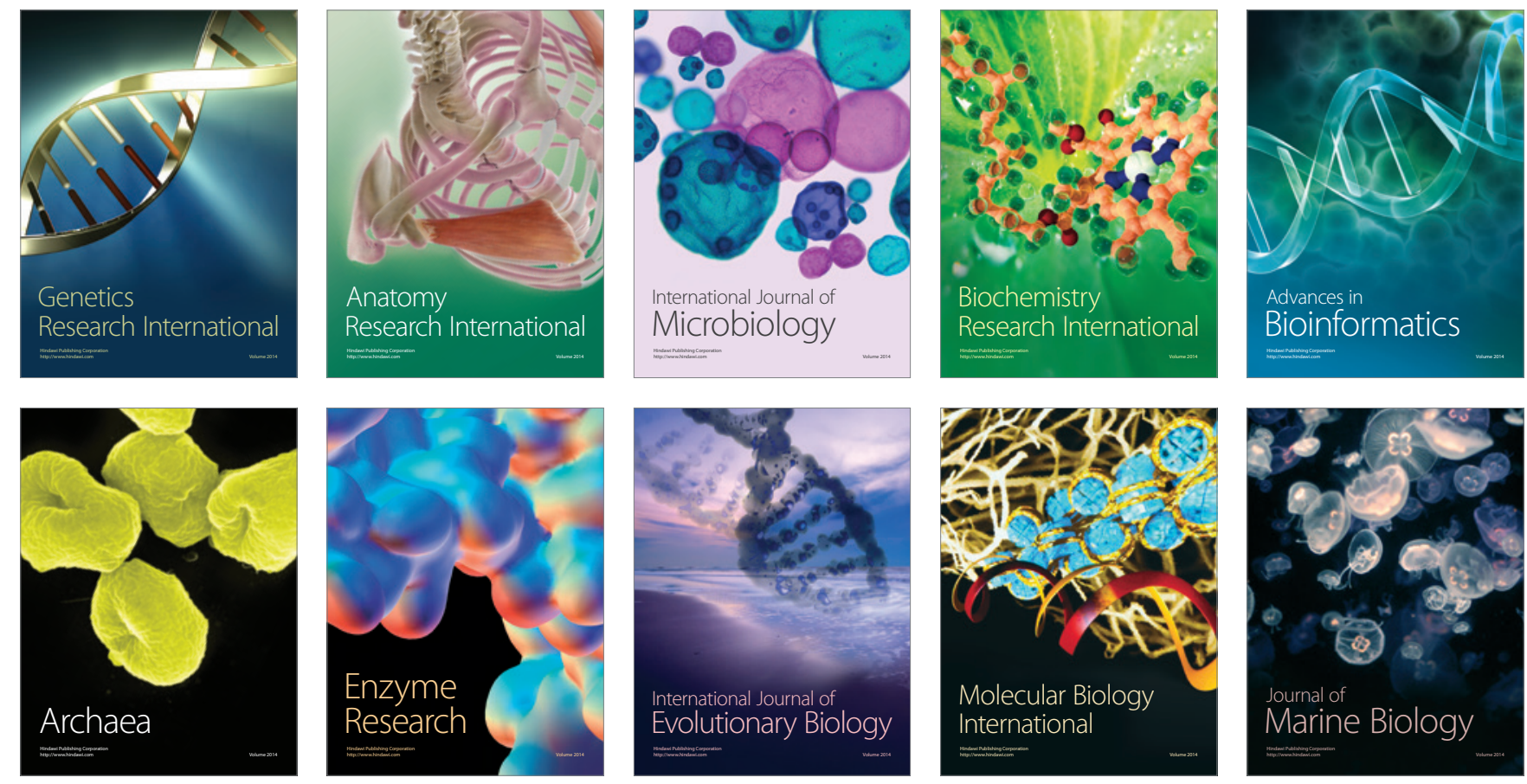